\title{
The Teachers' Online Readiness: an evaluation of Online Learning during Covid-19 Pandemic in Indonesia
}

\author{
Chandra Fitra Arifianto ${ }^{1 *}$, Mutawali ${ }^{2}$,and Heny Subekti ${ }^{3}$ \\ ${ }^{1,2,3}$ Pamulang University, Indonesia \\ *e-mail: dosen01177@unpam.ac.id
}

\begin{abstract}
Online learning is the right choice to do during the Covid-19 pandemic. So that the challenges that teachers in implementing learning must face are in themselves. Therefore, this study assesses the influence of attitudes, interests, and motivation on teachers' online readiness in learning from home due to the Covid-19 pandemic. This research is quantitative by using a questionnaire for data collection. The sample was determined using an accidental sampling method, namely elementary school teachers and equivalent to senior high school teachers and equivalent from all regions of Indonesia, totaling 281 respondents. While the analysis technique used is multiple linear regression. The results of this study indicate that attitude has a significant influence on online readiness, with the most dominant indicator being behavior, interest also has a significant influence on online readiness, with the most dominant indicator being personal, and motivation has a minor influence on online readiness with the most indicator dominant being external. While simultaneously, attitudes, interests, and motivation positively affect online readiness with a significance level of less than 0.005. Due to the limited variables chosen, it is recommended to enrich it using other variables in further research.
\end{abstract}

Keywords:

Teachers' Readiness; Attitudes; Interests; Motivation; Online Learning

\begin{abstract}
ABSTRAK
Pembelajaran daring menjadi pilihan tepat untuk dilakukan selama pandemi Covid-19. Sehingga tantangan yang harus dihadapi guru dalam melaksanakan pembelajaran ada pada dirinya. Sehingga penelitian ini bertujuan untuk mengukur pengaruh sikap, minat dan motivasi terhadap kesiapan daring guru dalam belajar dari rumah, akibat pandemi Covid-19. Penelitian ini bersifat kuantitatif dengan menggunakan kuesioner untuk
\end{abstract}


pengumpulan datanya. Penentuan sampel dilakukan dengan metode accidental sampling, yaitu guru SD dan sederajat hingga guru SMA dan sederajat dari seluruh wilayah Indonesia dengan responden yang berjumlah 281 guru. Sedangkan teknik analisis yang digunakan pada penelitian ini adalah regresi linier berganda. Hasil penelitian ini menunjukkan bahwa sikap memiliki pengaruh yang besar terhadap kesiapan daring dengan indikator yang paling dominan adalah perilaku, minat juga memiliki pengaruh yang besar terhadap kesiapan daring dengan indikator yang paling dominan adalah pribadi, dan motivasi memiliki pengaruh paling kecil terhadap kesiapan daring dengan indikator yang paling dominan pada motivasi adalah eksternal. Sedangkan secara simultan sikap, minat dan motivasi memiliki pengaruh positif terhadap kesiapan daring dengan tingkat signifikansi kurang dari 0,005. Karena keterbatasan variabel yang dipilih, maka disarankan untuk memperkayanya dengan menggunakan variabel lain pada penelitian selanjutnya.

Kata kunci:

Kesiapan Guru; Sikap; Minat; Motivasi; Pembelajaran Daring

\section{Introduction}

The first Covid-19 case in Indonesia was detected in March 2020. Over time, its spread has become more widespread. Thus, the Government quickly decided to work and study from home (Cahya, 2020). This urgent situation forces all parties to immediately transform to adapt to the circumstances of the Covid-19 pandemic. The Minister of Education and Culture has followed up by issuing a circular regarding online learning and working from home to prevent coronavirus disease (Covid-19). This policy, of course, strikes the actors of education. In the middle of the learning year, they were forced to change the face-to-face learning method into online learning. Online learning is a challenge for students because of its nature of being self-regulated and the distance between the instructor and students (Dorsah, 2021).

Some of the problems eventually overflowed with the imminent change in learning methods. New problems emerged, such as massive and short mastery of technology by teachers and unlimited time allocation for teachers (Purwanto et al., 2020), and preparation of facilities and infrastructure by schools and students quickly and accurately (Eddy \& Suryono, 2019). This sudden change impacts education actors, institutions or schools, and the teaching staff or teachers themselves. Schools (mainly private) will think again about teachers' productivity. Meanwhile, for teachers themselves, Fløvik, Knardahl and Christensen (2019) explain that health and changes in intention to work (teaching) will appear in the teacher's figure. Not to mention the demand to pursue the material in the curriculum in these conditions.

Since implementing this online education, UNESCO has recorded that at least 1.5 billion school-age children have been affected by Covid-19 (Suharwoto, 2020). Even though from the teacher's point of view, they also experience pressure when faced with online learning. Although 
few of them have done online learning before, that does not mean there are no problems. Windiarti et al. (2019) found problems faced by teachers in carrying out online learning, including the use of e-learning devices, teacher knowledge, time management, and of course, student motivation. The circumstances that forced them to move from offline learning to online learning immediately caused mass panic. Pragholapati (2020) concluded that during the Covid-19 pandemic, the levels of anxiety and depression in Chinese students exceeded national norms. This shows that a panic situation is breaking out. However, Dhawan (2020) believes that behind this catastrophe, there are benefits from online learning.

The panic experienced by the teacher meant that online learning was not optimal. Teacher readiness needs to be matured before being faced with the conditions of online learning. Considering the central role of teachers in education, learning activities need to be carried out immediately. Some of the preparations that need to be done by teachers include readiness to evaluate students' readiness, develop themselves to master the skills needed for online learning and manage their expectations about online learning through courses and tips (Joosten \& Cusatis, 2020). This will increase the chances of success in online learning. However, several aspects affect the readiness of the teachers.

It cannot be denied if the teacher is the primary key in learning. So that teacher performance needs to be well maintained. Moreover, conditions force them to be able to hold lessons even online. Therefore, Djaja (2017) stated that several things affect teachers' readiness in carrying out this online learning. Attitude, motivation, and perceptions are critical to the success of online learning programs for teachers. Besides that, Wong et al. (2020) added that interest is also an essential component in learning. So, researchers assess attitudes, motivation, and interests play an essential role in critical readiness to teach online. Moreover, there are not many studies that discuss online learning readiness in teachers. Research on online learning read

ness is dominated by students as research subjects. During the Covid-19 pandemic, there were several studies on online learning readiness in teachers, such as Scherer et al. (2021), who created a profile of secondary school teachers in which teachers' readiness for online learning depends on institutional, cultural, and innovation contexts. Furthermore, Hu, AlSaqqaf and Swanto (2020) discuss e-learning in English subjects in Sabah, Malaysia.

Attitude is a construct that is often used to assess individual behavior. In fact, since the $1920 \mathrm{~s}$ and 1930s, the measurement method has begun to be compiled (Hair Jr. et al., 2019). This is because there is no limit to the attitude itself. As long as human life lasts, there will always be learning embodied in the socialization process. Even some attitudes, such as belief in religion, will become resistant to change (Mullins, 2005).

Within the organization's scope, the attitude of employees (including teachers) can be reflected in job satisfaction and organizational commitment (Luthans, 2011). This will lead to an attitude to do more for organizations or what is better known as Organizational Citizenship 
Behavior (OCB). Later, employees/teachers will be able to do without others because they arise from their awareness and desire for the organization in which they are located. Therefore, this study divides the attitude into three components (Robbins \& Judge, 2013): cognitive, affective, and behavior.

In psychology, motivation is a psychological construct that is the impetus for a behavior or action to occur, both within oneself and as part of the organization. At the same time, LaRocque (2014) explained that motivation is the key to living within the individual. Without motivation, he/she is finished. Motivation itself is like the power to change their view of a problem it faces and be moved to solve it. Within the organization's scope, motivation is a way to create high enthusiasm for organizational goals, which accommodate the needs of life (LaRocque, 2014)

What is expected is that teachers have high productivity in providing learning. Therefore, motivation plays a vital role in this condition. In simple terms, Danim (2011) illustrates that if the measure of work motivation is productivity, it can be formulated that teacher motivation $(\mathrm{M})$ is a function of (f) teacher productivity (P) or $\mathrm{M}=$ (f.P). So that to become a productive teacher, one must be able to generate achievement motives that exist within him and which he may be able to awaken. Han \& Yin (2016) have identified if teacher motivation is the primary determinant in motivating students and teaching effectiveness.

Motivation involves energy, direction, persistence, and all aspects of doing something (intention). Therefore, it should generate motivation, where a teacher can move other people (students) to action. This study refers to Ryan and Deci (2000), where motivation in individuals consists of intrinsic motivation and extrinsic motivation, known as Self-Determination Theory. Through these abilities, individuals can make informed decisions, solve problems, think critically and creatively, communicate effectively, build relationships, empathize with others, manage and cope with their lives healthily and productively.

As the deliverer of the material, the teacher needs to find strategies to attract students' interest. Undoubtedly, the material will be conveyed more when interest has been formed. The interest and goals of students interact with the environment to be able to trigger situational interest. Such situational interest will enhance behavior and cognition and lead to better learning and grades (Kahu, Nelson, \& Picton, 2017). The main problem is how teachers can be interested in providing lessons to students, especially in online learning methods. Therefore, the study uses the following indicators from Hidi (2006), situational interest and personal interest.

Harackiewicz, Smith \& Priniski (2016) noted several main points on both interests. Interest is an increase in attention, effort, and influence on a particular object or topic and a persistent tendency to re-engage from time to time. So that integrating the two definitions can guide interventions that can develop or sustain interest. In addition, interventions on interest include getting attention, contexts that arouse prior individual interest, problem-based learning, and increasing utility values. However, interest is significant to academic success. Teacher preparation, 
interest-incentivized interventions, and accountability for interest can contribute to engaged and motivating learning experiences.

In the current era of the Covid-19 pandemic, educational institutions must prepare for urgent ICT needs. For that is the second choice that must be made. However, according to Pappas (2013), not all educational institutions are capable of preparing. Luckily there are many accessible ICTs available on the internet. There are hundreds of free applications that can be used for learning media. Therefore, this study uses the assumption that the media for online learning is readily available so that researchers feel the need to measure the readiness of teachers' online learning by using the Online Learning Readiness Scale with dimensions belonging to Hung et al. (2010), among others: Self-directed learning, motivation for learning, computer/internet self-efficacy, learner control, and online communication.

Research related to online learning readiness conducted by Dwiyanti, Pratama and Manik (2020) on junior high school students in Denpasar showed that the five dimensions of Hung et al. (2010), as a whole, describe the readiness of students, except for the dimension of self-directed learning which is considered not ready. Although the research is on students, researchers assume it can also describe the condition of the teachers.

Researchers also reminded that the ability to appreciate and take advantage of online learning depends on gender, length of online teaching, the delivery method of online learning given to teachers (Martin, Budhrani \& Wang, 2019), innovation potential in education, and cultural orientation (Scherer et al., 2021). Of course, many teachers have not yet learned how to convey online learning in the current condition. Therefore, it is hoped that this research will find what variables are dominant in shaping teachers' readiness in providing online learning.

Online learning is challenging to do. The participants experienced many obstacles. Baticulon et al. (2020) comb the obstacles in online learning: technology, individuals, domestic, institutional, and community. The main problem faced is physical and mental capacity in dealing with online learning. This is what is described as attitude. Similarly, research conducted by Nachimuthu (2020) in Tamil Nadu, Southern India, showed that teacher attitudes towards online learning during Covid19 showed a positive and significant effect. Besides preparing the material being taught, the teacher must also encourage students to be more physically and psychologically active.

When discussing motivation, of course, it cannot be separated from what is in a person. How does he have the desire to move? How does he feel, which prompts him to do something? Including the desire to do online learning. Online learning readiness cannot be separated from motivational involvement (both extrinsically and intrinsically). Setiawan, Sawitri and Suswati (2019) have proven that interest in learning readiness has been proven to positively affect the army polytechnic students in Batu City, Indonesia. However, what distinguishes this research is that the subjects used are diploma students and offline learning. Furthermore, in discussing the dimensions of Online 
Learning Readiness by Hung et al. (2010), all dimensions affect motivation. This proved that there is indeed an effect of motivation and online learning readiness.

Ko \& Rossen (2017) stated that technicians do not always make the best for online learning instructors. Interest in teaching comes first, meanwhile second technology. So it can be understood if the most important thing in online learning is still the teacher him/herself. Geng, Law \& Niu (2019) put forward the same emphasis, where interest has an essential role in learning readiness by utilizing technology in students. Sun and Rueda (2011) have identified a correlation between situational interest and learning in distance education settings at universities in the southwestern US.

The conceptual framework is a synthesis of the relationship between variables compiled from various theories that have been described, then analyzed critically and systematically, resulting in a synthesis of the relationship. These variables are then used to formulate hypotheses (Sugiyono, 2009). The design of this study consists of independent and dependent variables. The independent variable is the variable attitude (X1), interest (X2), and motivation (X3). The dependent variable is online learning readiness (Y). So, the framework and hypothesis of this study can be proposed and explained in Figure 1.

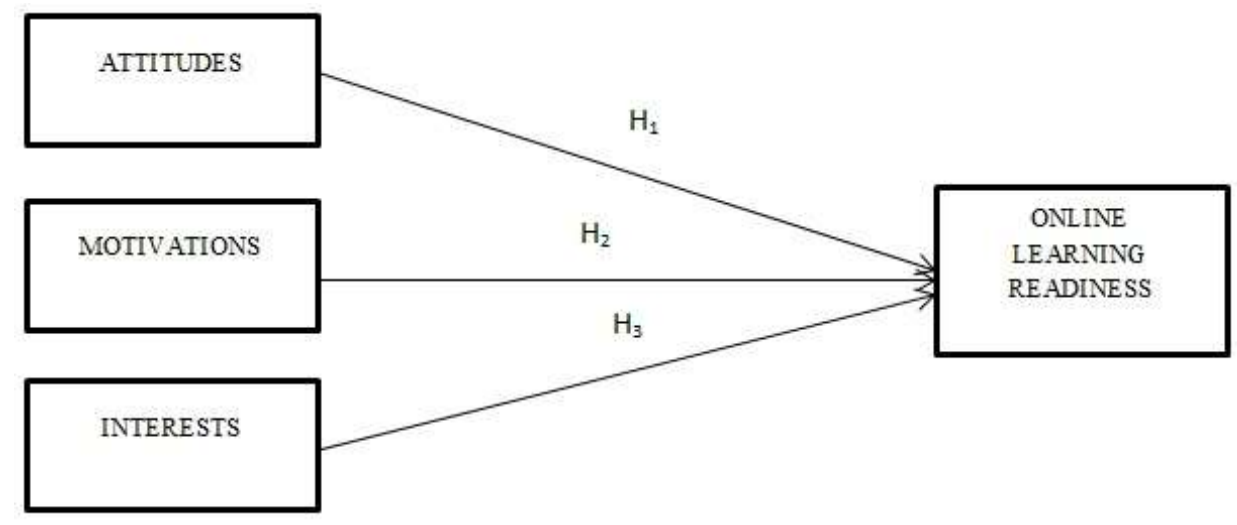

Figure 1. Conceptual Framework

Referring to the framework of thinking, this research will look at the influence of attitudes, motivations, and interests on the online learning readiness of Indonesian teachers during the Covid19 pandemic. This study believes that by knowing the most influencing variables, the relevant agencies can make the basis for issuing policies. Because the online learning policy is still running, the research will answer many teachers' experiences when carrying out online learning. 


\section{Methods}

\subsection{Types of Research}

This study used a quantitative approach that aims to test hypotheses that have been designed, as in Figure 1. This study wanted to determine the effect of the independent variables (attitudes, motivations, and interests) on the dependent variable (online learning readiness). So that the hypotheses compiled in this study are as follows:

$\mathrm{H}_{1} \mathrm{O}$ : Attitude has no significantly affected the online learning readiness of the teacher

$\mathrm{H}_{1} \mathrm{a}$ : Attitude significantly affects the online learning readiness of the teacher

$\mathrm{H}_{2} \mathrm{O}$ : Motivation has no significantly affected the online learning readiness of teachers

$\mathrm{H}_{2} \mathrm{a}$ : Motivation significantly affects the online learning readiness of teachers

$\mathrm{H}_{3} \mathrm{O}$ : Interest has non significantly affects the online learning readiness of the teacher

$\mathrm{H}_{3} \mathrm{a}$ : Interest significantly affects the online learning readiness of the teacher

\subsection{Population and Sample}

Respondents in this research are teachers in private and public schools at the elementary, junior high, and high school levels who implemented online teaching and learning activities in the territory of Indonesia. The total population is the primary consideration for researchers in determining the number of samples. So that in this study, the determination of the sample using accidental sampling, where the sampling unit is selected based on its availability. However, in this study, the researcher decided to use more respondents, 281 respondents, to represent each level of education. Table 1 shows the number of respondents who represent each level of education.

\subsection{Data Collection Techniques and Data Collection Instruments}

From the sample determined by this study, distributed questionnaires to 281 respondents. Collecting data in this study using primary and secondary data. As the primary data, researchers used a questionnaire. A questionnaire was distributed to teachers as respondents. This was distributed from April to July 2020 using Google Form media. This media was chosen because of the implementation of national-scale social restrictions. The instrument in this study used a questionnaire that refers to Likert. The four variables were measured using a Likert scale, where the score was 1 for the lowest level and 5 for the highest level. As for secondary data, researchers used literature books, journals, and the internet to support this research. 


\subsection{Data Analysis}

The data analysis technique used multiple linear regression with the SPSS as a data processing tool in this study. Researchers conducting this test have stages starting from testing traditional assumptions, consisting of normality test, linearity test, multicollinearity test, heteroscedasticity test, and autocorrelation test. After that, it is continued with the regression coefficient test, $\mathrm{t}$-test, and $\mathrm{f}$ test.

Table 1. Description of the respondent's identity

\begin{tabular}{lcccccccc}
\hline & \multicolumn{3}{c}{ Gender } & \multicolumn{3}{c}{ School Level } & \multicolumn{3}{c}{ Been a teacher for .... years } \\
\hline & $\mathrm{M}$ & $\mathrm{F}$ & Element. & Junior HS & Senior HS & $<5 \mathrm{y}$ & $5-10 \mathrm{y}$ & $>10 \mathrm{y}$ \\
$\begin{array}{l}\text { Amounts } \\
\text { (persons) }\end{array}$ & 94 & 187 & 97 & 46 & 138 & 57 & 75 & 149 \\
$\%$ & 33.45 & 66.55 & 34.51 & 16.37 & 49,12 & 20.28 & 26.69 & 53.03 \\
\hline
\end{tabular}

\section{Results and Discussion}

\subsection{Results}

The results directly present the data and results obtained from the study. This section only provides a narrative description of the research results without any interpretation. The discussion section interprets the meaning of the research results, whether following expectations or not. The following shows the results of the research.

Table 2 explains the value of the correlation/relationship (R), which is 0.694. From this output, the coefficient of determination (R Square) is 0.482 , which implies that the influence of the independent variables (attitude, motivation, and interest) on the related variable (online learning readiness) is $48.2 \%$.

Table 2. Model Summary

\begin{tabular}{cccccc}
\hline Model & $\mathbf{R}$ & R Square & $\begin{array}{c}\text { Adjusted R } \\
\text { Square }\end{array}$ & $\begin{array}{c}\text { Std. Error of the } \\
\text { Estimate }\end{array}$ & Durbin-Watson \\
\hline 1 & $.694^{\mathrm{a}}$ & .482 & .477 & 7.865 & 1.927 \\
\hline
\end{tabular}

Table 3. ANOVA

\begin{tabular}{llccrrc}
\hline Model & $\begin{array}{c}\text { Sum of } \\
\text { Squares }\end{array}$ & Df & Mean Square & F & Sig. \\
\hline 1 & Regression & 15953.296 & 3 & 5317.765 & 85.966 & $.000^{\mathrm{b}}$ \\
& Residual & 17134.953 & 277 & 61.859 & & \\
& Total & 33088.249 & 280 & & & \\
\hline
\end{tabular}

a.Dependent Variable: Online Learning Readiness

b.Predictors: (Constant), Interest, Attitude, Motivation

Table 3 shows that the calculated $F$ value is 85.966, with a significance level of $0.000<0.05$. Then the regression model can be used to predict the participation variable, or in other words, there 
is the influence of the variable attitude (X1), motivation (X2), interest (X3) on the online learning readiness variable $(\mathrm{Y})$. It is known (see table 4) that the constant value (a) is 4.511 while the Attitude value (with regression coefficient X1) is 1.190 , the Motivation value (with regression coefficient X2) is 0.425 , and the Interest value (with regression coefficient X3) is 0,779 .

Table 4. Coefficient

\begin{tabular}{|c|c|c|c|c|c|}
\hline \multirow[t]{2}{*}{ Model } & \multicolumn{2}{|c|}{$\begin{array}{l}\text { Unstandardized } \\
\text { Coefficients }\end{array}$} & \multirow{2}{*}{$\begin{array}{c}\text { Standardized } \\
\text { Coefficients } \\
\text { Beta }\end{array}$} & \multirow[t]{2}{*}{$\mathbf{T}$} & \multirow[t]{2}{*}{ Sig. } \\
\hline & B & Std. Error & & & \\
\hline (Constant) & 4.511 & 4.359 & & 1.035 & .302 \\
\hline Attitude & 1.190 & .137 & .461 & 8.699 & .000 \\
\hline Motivation & .425 & .160 & .147 & 2.649 & .009 \\
\hline Interest & .779 & .151 & .250 & 5.165 & .000 \\
\hline
\end{tabular}

a. Dependent Variable: Online Learning Readiness

Based on table 4, the regression equation can be written:

$\mathrm{Y}=\mathrm{a}+\mathrm{bX} 1+\mathrm{bX} 2+\mathrm{bX} 3$

$\mathrm{Y}=4,511+1,190 \mathrm{X} 1+0,425 \mathrm{X} 2+0,779 \mathrm{X} 3$

The equation above can be translated:

a) A constant of 4.511 means that the consistent value of the participation variable is 4.511.

b) The X1 regression coefficient of 1.190 states that every $1 \%$ addition of the Online LearningReadiness value, the Attitude value increases 1.190 . The regression coefficient is positive, so it can be said that the direction of the influence of variable $\mathrm{X} 1$ on $\mathrm{Y}$ is positive.

c) The X2 regression coefficient of 0.425 states that every $1 \%$ addition of the Online Learning Readiness value, then the Motivation value increases by 0.425 . The regression coefficient is positive, so it can be said that the direction of the influence of variable X2 on $\mathrm{Y}$ is positive.

d) The $\mathrm{X} 3$ regression coefficient of 0.779 states that every $1 \%$ addition of the Online Learning Readiness value, then the Interest value increases 0.779 . The regression coefficient is positive, so it can be said that the direction of the influence of the X3 variable on $\mathrm{Y}$ is positive.

\subsection{Discussion}

This research is deliberately focused on teachers rather than students. So that the results of this study will enrich the knowledge of the teacher figure. The psychological side is the primary variable in seeing the teacher as a human figure, like others. Attitudes, motivations, and interests, 
which are also common to humans, will undoubtedly be different for teachers who face online learning with short preparations due to the Covid-19 pandemic. The impact of these three factors can at least be a significant concern during online learning.

The calculation that has been presented previously is known that the variable X1 (Attitude), the value of $\mathrm{T}$ count is 8.699 with a significance level of $0.000<0.05$, so the regression model can be used to predict the participation variable or, in other words, the Attitude variable (X1) affects the Online Learning. The results of this study show similarities to what happened in India. Nachimuthu (2020) found that the attitude of students and teachers towards online learning during COVID-19 is positive and is the right solution during the lockdown period. Readiness variable (Y). Furthermore, the variable X2 (Motivation), the T value is 2.649 with a significance level of $0.009<0.05$, then the regression model can be used to predict the participation variable, or in other words, the variable Motivation (X2) affects the Online Learning Readiness variable (Y). This strengthens the research conducted by Setiawan, Sawitri and Suswati (2013), which states that there is an influence of learning motivation on student readiness to learn in Batu, Indonesia. So there is no difference between online and offline learning in learning readiness as long as motivation always exists and is maintained.

Meanwhile, variable X3 (Interest), the value of $\mathrm{T}$ count is 5.165 with a significance level of $0.000<0.05$, then the regression model can be used to predict the participation variable, or in other words, the Interest variable (X3) affects the Online Learning Readiness variable (Y). This is the same as the result of research conducted by Sun \& Rueda (2011), but the indicators that affect online learning readiness are different. This is possible due to different conditions where currently, all learning is forced to be done online.

In online learning, research by Bovermann, Weidlich and Bastiaens (2018) showed the same results as the results of this study, which found a positive influence on both motivation and attitudes towards online learning readiness. It is just that several things can affect it, namely social competencies and technical competencies. So that the competence factor, which affects the role as a teacher, may be considered for further analysis as Alvarez, Guasch and Espasa (2009) did. Wang et al. (2021) emphasize that internal psychological mechanisms play a role in shaping teacher interest and motivation in responding to online learning. Even art teachers can adapt by embracing online learning to serve as an encouragement to show a professional side.

However, it cannot be denied that teachers should keep up with the changing times. Gradually, the use of online education needs to be done. Blended learning is the right choice for use in the new normal learning setting. Both teachers and students, even though they do face-to-face teaching, online material giving is also applied. Learning like this provides many benefits both in terms of time, effort to go to school, and use of school facilities (Dziuban et al., 2018). 


\section{Conclusions}

This study indicates that attitude (X1) influences online learning readiness (Y), with the most dominant indicator being behavior. Motivation (X2) also has a significant influence on online learning readiness (Y), with the most dominant indicator being external.. and interest (X3) has little effect on online readiness (Y), with the most dominant indicator being Personal. Meanwhile, simultaneously, Attitude (X1), Motivation (X2), and Interest (X3) have a positive influence on the Online Learning Readiness variable (Y).

Furthermore, this study also has limitations on the selected variables. Recommendations for future research developers can enrich the indicator variables related to online learning and enrich the number of primary sources in analyzing this research. Furthermore, it is necessary to also examine online learning with factors that affect readiness to learn online, such as inadequate facilities (Eze et al., 2018) on the part of teachers and parents, which ends with the opinion that online learning is challenging to do (Schleicher, 2020).

\section{References}

Alvarez, I., Guasch, T., \& Espasa, A. (2009). University teacher roles and competencies in online learning environments: a theoretical analysis of teaching and learning practices. European Journal of Teacher Education, 32(3), 321-336. DOI:10.1080/02619760802624104

Baticulon, R.E., Alberto, N.R.I., Baron, M.B.C., Mabulay, R.E.C., Rizada, L.G.T., Sy, J.J., Tiu, C.J.S., Clarion, C.A., \& Reyes, J.C.B. (2020). Barriers to Online Learning in the time of COVID-19: A National Survey of Medical Students in the Philippines. medRxiv, 2020.07.16.20155747. DOI: https://doi.org/10.1101/2020.07.16.20155747.

Bovermann, K., Weidlich, J., \& Bastiaens, T. (2018). Online learning readiness and attitudes towards gaming in gamified online learning - a mixed-methods case study. International Journal of Educational Technology in Higher Education, 15 (27). DOI:https://doi.org/10.1186/s41239-018-0107-0

Cahya, G. (2020, 16 March). Stay home, President says. The Jakarta Post. Retrieved from https://www.thejakartapost.com/news/2020/03/16/stay-home-president-says.html.

Danim, S. (2011). Pengembangan Profesi Guru: Dari Pra-Jabatan, Induksi, ke Profesional Madani [Teacher Professional Development: From Pre-Service, Induction, to Civil Professionals]. Jakarta: Kencana.

Dorsah, P. (2021). Pre-service Teachers' Readiness for Emergency Remote Learning in the Wake of COVID-19. European Journal of STEM Education, 6 (1), 1-12. DOI: https://doi.org/10.20897/ejsteme/9557.

Dwiyanti, K.E., Pratama, I.P.Y., \& Manik, N.P.I.M.C. (2020). Online Learning Readiness of Junior High School Students in Denpasar. Indonesian Journal of English Education, 7 (2), 172-188. DOI: http://doi.org/10.15408/ijee.v7i1.17773.

Dziuban, C., Graham, C.R., Moskal, P.D., Norberg, A., \& Sicilia, N. (2018). Blended learning: the new Normal and Emerging Technologies. International Journal of Educational Technology in Higher Education, 15 (3), 1-16. DOI: 10.1186/s41239-017-0087-5.

Eddy, G.S. \&Suryono, Y. (2019). Implementation of Online Learning Lessons in the Package C Program. Journal of Nonformal Education, 5(2), 117-124. DOI: 10.15294/jne.v5i2.20355. 
Eze, S.C., Chinedu-Eze, V.C. \& Bello, A.O. (2018). The Utilisation of e-learning facilities in the educational delivery system of Nigeria: a Study of M-University. International Journal of Educational Technology in Higher Education, 15 (34). DOI: https://doi.org/10.1186/s41239018-0116-z

Fløvik, L., Knardahl, S. \& Christensen, J.O. (2019). The Effect of Organizational Changes on the Psychosocial Work Environment: Changes in Psychological and Social Working Conditions Following Organizational Changes. Frontiers in Psychology, 10(2845), 1-18. DOI: 10.3389/fpsyg.2019.02845.

Geng, S., Law, K.M.Y. \& Niu, B. (2019). Investigating Self-directed Learning and Technology Readiness in Blending Learning Environment. International Journal of Education Technology in Higher Education, 16 (17), 1-22. DOI:https://doi.org/10.1186/s41239-019-0147-0.

Hair Jr., J.F., Gabriel, M.L.D.S., Silva, D., \& Junior, S.B. (2019). Development and Validation of attitude Measurement Scales: Fundamental and Practical Aspects. RASP Management Journal, 54(4), 490-507. DOI: 10.1108/RAUSP-05-2019-0098.

Han, J. \& Yin, H. (2016). Teacher motivation: Definition, research development and implications for teachers. Cogent Education, 3(1). DOI:10.1080/2331186x.2016.1217819

Harackiewicz, JM,. Smith, JL., Priniski, SJ., (2016). Interest Matters: The Importance of Promoting Interest in Education, Policy Insights Behav Brain Sci 3 (2) 220-227. DOI: $10.1177 / 2372732216655542$

Hidi, S. (2006). Interest: A Unique Motivational Variable. Educational Research Review, 1 (2), 6982. DOI: 10.1016/j.edurev.2006.09.001.

Hu, K., AlSaqqaf, A., \& Swanto, S. (2020). E-learning Readiness among English Language Teachers in Sabah, Malaysia: A Pilot Study. Journal of English Language Teaching Innovation and Materials, 2(2), 120-127. DOI: http://dx.doi.org/10.26418/jeltim.v1i1.42155

Hung, M.L., Chou, C., Chen, C.H., \& Own, ZY (2010). Learner Readiness for Online Learning: Scale Development and Student Perceptions. Computers \& Education,55 (3), 1080-1090. DOI: 10.1016/j.compedu.2010.05.004.

Joosten, T. \&Cusatis, R. (2020). Online Learning Readiness. American Journal of Distance Education, 34(3), 180-193. DOI: 10.1080/08923647.2020.1726167.

Kahu, E., Nelson, K.\& Picton, C. (2017). Student interest as a key driver of engagement for FirstYear Students. Student Success, 8 (2), 55-66. DOI: 10.5204/ssj.v8i2.379.

Ko, S. \& Rossen, S. (2017). Teaching Online: A Practical Guide (Fourth Edition). New York: Routledge.

LaRocque, C.(2014). Life is Motivation: If You want to Lead the Pack, Work Harder than the Pack. Victoria: Friesenpress.

Luthans, F. (2011). Organizational Behavior: An Evidence-Based Approach (12th ed.). New York: McGraw-Hill/Irwin.

Martin, F., Budhrani, K. \& Wang, C. (2019). Examining Faculty Perception of Their Readiness to Teach Online. Online Learning, 23 (3), 97-119. DOI: 10.24059/olj.v23i3.1555.

Mullins, L. (2005). Management and Organisational Behaviour (7th ed.). Essex: Pearson.

Pragholapati, A. (2020). COVID-19 impact on students. EdArXiv [Preprint], 1-6. DOI:10.35542/osf.io/895ed

Purwanto, A., Pramono, R., Asbari, M., Hyun, C.C., Wijayanti, L.M., Putri, R.S., \& Santoso, P.B. (2020). Studi Eksploratif Dampak Pandemi COVID-19 Terhadap Proses Pembelajaran Online di SekolahDasar [Exploratory Study of the Impact of the COVID-19 Pandemic on Online Learning Process in Primary Schools]. EduPsyCouns: Journal of Education, Psychology and 
Counseling, 2(1), 1-12. Retrieved from https://ummaspul.ejournal.id/Edupsycouns/article/view/397/223.

Robbins, S. \& Judge, T.(2013). Organizational behavior (15th ed.). Boston: Pearson.

Ryan, R.\& Deci, E. (2000). Self-Determination Theory and the Facilitation of Intrinsic Motivation, Social Development, and Well-Being.American Psychologist, 55 (1), 68-78.DOI: 10.1037110003-066X.55.1.68.

Scherer, R., Howard, S.K., Tondeur, J., \& Siddiq, F. (2021). Profiling teachers' Readiness for Online Teaching and Learning in Higher Education: Who's ready? Computers in Human Behavior, 118, 106675. DOI: https://doi.org/10.1016/j.chb.2020.106675.

Schleicher, A. (2020). TALIS 2018: Insights and Interpretations. OECD Publishing.

Setiawan, A., Sawitri, D. \& Suswati, E. (2019). Pengaruh Minat dan Lingkungan Belajar terhadap Kesiapan Belajar dimediasi oleh Motivasi Belajar [The Influence of Interest and Learning Environment on Learning Readiness is mediated by Learning Motivation]. Jurnal Psikologi, 6 (2), 94-113. Retrieved from https://jurnal.yudharta.ac.id/v2/index.php/ILMUPSIKOLOGI/article/view/1830.

Sugiyono,. (2009). Metode Penelitian Bisnis [Business Research Methods]. Bandung: CV. Alfabeta.

Suharwoto, G. (2020, 2 April). Pembelajaran Online di Tengah Pandemi Covid-19, Tantangan yang Mendewasakan [Online Learning Amid the Covid-19 Pandemic, a Maturing Challenge]. Timesindonesia.co.id. Retrieved from https://www.timesindonesia.co.id/read/news/261667/pembelajaran-online-di-tengah-pandemicovid19-tantangan-yang-mendewasakan.

Sun, JCY \& Rueda, R. (2011). Situational Interest, Computer Self-efficacy, and Self-regulation: Their impact on Student Engagement in Distance Education. British Journal of Educational Technology, 43 (2), 191-204. DOI: 10.1111/j.1467-8535.2010.01157.x

Wang, M., Wang, M., Cui, Y., \& Zhang, H. (2021). Art Teachers' Attitudes Toward Online Learning: An Empirical Study Using Self Determination Theory. Front. Psychol. 12 (627095). DOI: 10.3389/fpsyg.2021.627095

Windiarti, S., Fadilah, N., Dhermawati, E. \& Pratolo, B.W. (2019). Teacher's Perception toward the Obstacles of E-Learning Classes. Ethical Lingua: Journal of Language Teaching and Literature, 6(2), 117-128. Retrieved from https://ethicallingua.org/25409190/article/view/38.

Wong, L.H., Chan, T.W., Chen, W., Looi, C.K., Chen, Z.H., Liao, C.C.Y., King, R.B., \& Wong, S.L. (2020). IDC Theory: Interest and the Interest Loop. Research and Practice in Technology Enhanced Learning, 15(3), 1-16. DOI: 10.1186/s41039-020-0123-2. 